\title{
OWNER CHARACTERISTICS AND FIRM PERFORMANCE DURING THE GREAT RECESSION
}

by

\author{
Ron Jarmin ${ }^{1}$ \\ U.S. Census Bureau
}

C.J. Krizan ${ }^{2}$

U.S. Census Bureau

\author{
Ade la Luque ${ }^{3}$ \\ U.S. Census Bureau
}

\section{CES 14-36 September, 2014}

The research program of the Center for Economic Studies (CES) produces a wide range of economic analyses to improve the statistical programs of the U.S. Census Bureau. Many of these analyses take the form of CES research papers. The papers have not undergone the review accorded Census Bureau publications and no endorsement should be inferred. Any opinions and conclusions expressed herein are those of the author(s) and do not necessarily represent the views of the U.S. Census Bureau. All results have been reviewed to ensure that no confidential information is disclosed. Republication in whole or part must be cleared with the authors.

To obtain information about the series, see www.census.gov/ces or contact Fariha Kamal, Editor, Discussion Papers, U.S. Census Bureau, Center for Economic Studies 2K132B, 4600 Silver Hill Road, Washington, DC 20233, CES.Papers.List@census.gov. 


\begin{abstract}
Minority owned businesses are an increasing important component of the U.S. economy, growing at twice the rate of all U.S. businesses between 2002 and 2007. However, a growing literature indicates that minority-owned businesses may have been especially impacted by the Great Recession. As house prices declined, foreclosures fell disproportionately on urban minority neighborhoods and one of the sources of credit for business owners was severely constrained.

Using 2002-2011 data from the Longitudinal Business Database linked to the 2002 Survey of Business Owners, this paper adds to the literature by examining the employment growth and survival of minority and women employer businesses during the last decade, including the Great Recession. At first glance, our preliminary findings suggest that black and women-owned businesses underperform white, male-owned businesses, that Asian-owned businesses outperform other groups, and that Hispanic-owned businesses outperform non-Hispanic ones in regards to employment growth. However, when we look only at continuing firms, black-owned businesses outperform white-owned businesses in terms of employment growth. At the same time, we also find that the recession appears to have impacted black-owned and Hispanic-owned businesses more severely than their counterparts, in terms of employment growth as well as survival. This is also the case for continuing black and Hispanic-owned firms.
\end{abstract}

\footnotetext{
We thank the Kauffman Foundation for financial support. Any opinions and conclusions expressed herein are those of the author(s) and do not necessarily represent the views of the U.S. Census Bureau. All results have been reviewed to ensure that no confidential information is disclosed.

${ }^{1}$ Research and Methodology Directorate, U.S.Census Bureau: ron.s.jarmin@census.gov

${ }^{2}$ Center for Economic Studies, U.S. Census Bureau:cornell.j.krizan@census.gov

${ }^{3}$ Center for Administrative Records Res earch and Applications: U.S. Census Bureau, adela.luque@census.gov
} 


\section{Introduction:}

In this paper, we explore whether the Great Recession had differential impacts on business performance across owner characteristics. We are motivated by several broad findings in the literature. First, there is a long literature documenting the underperformance of minority and women owned businesses (see Fairlie and Robb 2008 for an overview). Much of this literature focuses on the lack of business capital available to minority and women owned firms as a primary driver of the observed underperformance of these businesses. Second, recent papers by Fort et al. (2013), Adelino et al. (2014) and Kristoph (2013) demonstrate that young and small businesses were disproportionately impacted during the Great Recession. The papers are consistent with a collateral channel impact of the run up in housing prices and subsequent subprime crisis where small and young businesses became severely credit constrained after housing prices fell. ${ }^{4}$ Finally, evidence shows that foreclosures fell disproportionately on urban minority neighborhoods (see Geradi and Willen 2009, and Rugh and Massey 2010).

Taken together these findings suggest that minority owned businesses may have been particularly hard hit during the Great Recession if owners depend on home equity as a means to provide capital to their businesses. We explore the role of owner characteristics on business performance over the period from 2002 to 2011, which includes both the run-up in housing prices and the Great Recession. We utilize data from the Census Bureau's Survey of Business Owners (SBO) which is conducted as part of the quinquennial Economic Census. We link 2002 SBO businesses to annual establishment data contained in the Census Bureau's Longitudinal Database (LBD). The linked SBO-LBD data allow us to follow the SBO firms over the entire period. We examine two business performance measures: employment growth and business survival. We compare performance across business owner characteristics to explore whether the Great Recession had differential impacts.

Like much of the literature, our preliminary results find that black and women-owned businesses underperform white, male-owned businesses and that Asian-owned businesses either outperform other groups or their performance is statistically undistinguishable from white-owned firms. How ever, when we look only at continuing firms, black-owned businesses outperform white-owned businesses in terms of employment growth. Regarding survival, we also find that the recession appears to have exacerbated survival probability differentials across race and Hispanic origin.

\footnotetext{
${ }^{4}$ Mian and Sufi(2011) find no evidence of a collateral channel and argue that the subprime crisis impacted the real economy primarily via an aggregate demand channel.
} 


\section{Background}

There is a large literature documenting that within any given geographic region, business characteristics and outcomes vary considerably across the entrepreneurs' personal characteristics. Robb and Fairlie (2006) show that black-owned firms have lower sales, profits, and probability of having employees and are more likely to close than are white- or Asian-owned businesses. Robb and Fairlie (2007) show that Asian-owned businesses are less likely to close, more likely to have higher profits and be bigger than white-owned firms. Fairlie (2008) argues that immigrant businesses make big contributions to the U.S. economy. Jarmin and Krizan (2010) find the black and women owned firms are slightly less likely than white and male owned firms to export while Hispanic and Asian owned firms are more likely to export that non-Hispanic and white owned businesses.

These cross-group differences in firm performance are generally thought to arise from differences across the groups in prior w ork experience, family business backgrounds, and availability of capital. Fairlie and Robb (2007) report that more than half of the white business owners had another family member who was already self-employed when they started their own business, compared to only a third for black owners. In fact, they point to a long history of studies showing that weak networking opportunities put potential black entrepreneurs at a disadvantage compared to their white (and Asian) counterparts. ${ }^{5}$ Moreover, Fairlie and Robb (2007) show that white-owned businesses often get passeddown to future generations.

By contrast, Asian entrepreneurs may be slightly less likely than their white counterparts to have had a self-employed family member, and key factors of their relative success are higher levels of human and start-up capital (Robb and Fairlie 2007).

Differences in the availability of start-up capital are also a contributing factor to why womenowned businesses are less successful than male-owned businesses (Fairlie and Robb 2008) - although systematic differences in firm and owner characteristics have been found to explain large parts of the observed differences in lending patterns (Robb and Wilken 2002). For example, Robb and Wilken (2002) found that woman-owned firms are younger, smaller and more likely to be engaged in retail trade. Nonetheless, new studies continue to document a disparity in the amount of start-up capital that men and women can raise and in the sources of the debt they incur (Coleman and Robb 2008).

\footnotetext{
${ }^{5}$ See for example Glazer and Moynihan (1970), Hout and Rosen (2000), and Fairlie (1999).
} 
The age of the potential entrepreneur can also affect business entry and success. It is also an important factor in both the likelihood of starting a business as well as a predictor of the business' success. For example, Kim (2007) studies the incidence of self-employment over a person's life cycle and finds that self-employment probabilities increase with age (and education). Several studies have examined the interaction of owner age with business performance with mixed results. Harhoff, Stahl, and Woywode (1998) show that voluntary liquidation increases with age but business insolvency does not, suggesting that retirement is an important factor in the decision of older entrepreneurs to close their business. Headd (2002) found that businesses owned by younger people are more likely to close - but also more likely to be profitable at the time of closure. Similarly Van Praag (2001) found that the older an entrepreneur is when they start a business, the longer the business will survive, but that there is a negative correlation between the owner's age and the profitability of the business when it shuts down.

Recent papers have analyzed the impact of the Great Recession on young and small business. Fort et. al. (2013) find young business exhibit more sensitivity to cyclical fluctuations. Moreover, they find that during the Great Recession the decline in the differentials of employment growth rates between young small business and larger more mature business were bigger in areas more impacted by declines in housing prices even after controlling for state level economic conditions. Adelino, Ma and Robinson (2014) find evidence that start-ups are more sensitive to local economic conditions than more mature firms. Their findings also support the notion that access capital (or lack thereof) is a critical factor in the ability of young startups to respond to shocks. Kliener (2013) examines the role housing collateral for small firms. He finds that housing prices declines explain between 20 and 37 percent of the employment loss at small firms in the areas most impacted by the housing crisis.

Gerardi and Willen (2009) show that the subprime housing crisis impacted urban minority neighborhoods disproportionately. Rugh and Massey (2010) discuss both the impact of the crisis on minority households and factors that made these communities especially susceptible to the subprime crisis. To the extent that minority business owners depended on pre-crisis increases in housing asset values to provide capital to their business, we might expect the crisis to put those businesses at risk especially when also faced with reduced demand from overall impact of the business cycle.

\section{Data}

The SBO is a comprehensive, regularly collected survey of the demographic and economic characteristics of business owners. It is a firm-level survey and its sample frame includes all nonfarm businesses with annual receipts of one thousand dollars or more. We use the SBO to get information on 
key demographic characteristic so the business ow ners such as: race, Hispanic origin, gender, and age. The SBO is conducted every 5 years in years ending in a "2" or a "7". We use data from the 2002 SBO.

Our other main data set, the Longitudinal Business Database (LBD), ${ }^{6}$ is a longitudinal annual database covering all U.S. establishments and firms in the non-farm business sector from 1976 to 2011 and includes information about payroll, employment, detailed location, detailed industry, and ownership structure. We link the SBO files to the LBD using a firm-level identifier common to both files. Once the SBO is linked to the LBD, we can look forward and backward to obtain information such as the age, size, industry or location of the firm, and also calculate performance measures such as employment growth and survival.

The 2002 SBO file includes 3,599,645 firms. ${ }^{7}$ Our sample consists of employer businesses for which an owner (or owners) is identified. ${ }^{8}$ Therefore, sole proprietors and partnerships are included in our sample while corporations and non-profit organizations are not. We also exclude any observation with missing or incomplete information on the race, ethnicity, gender, age or education of the business owner. We also require that the SBO firms match to the LBD. Our final sample includes 647,369 firms from the 2002 SBO.

Because we lose a large number of observations, it may not be appropriate to use the sample weights in our regression analysis. To account for our loss of observations, we follow Davis, Haltiwanger, Jarmin, Lener and Miranda’s (2013) methodology and develop a set of propensity score weights that account for the likelihood that a firm is included in our final sample. We compared the results from using both the sample and propensity score weights to the unweighted results and found little difference between them. ${ }^{9}$ In the remainder of the paper, the results reported are based on the unw eighted sample.

Table 1 both illustrates the small effects of using the weights and provides intuition for why they do not affect qualitative results. It compares the data on demographic owner characteristics as well as firm characteristics across the unweighted and weighted samples. Note that the differences between the two groups are small and most of them are within 1 or 2 percentage points of each other. The biggest difference is in the distribution of firm size, where the smallest firms (0 to 9 employees) represent a bigger share in the weighted sample. Finally, note that Table 1 reports the shares as of 2002. This is

\footnotetext{
${ }^{6}$ See Jarmin and Miranda (2002) for information on the creation and development of the LBD.

${ }^{7}$ The sample includes a weighting variable used to obtain business population totals of roughly 7 million firms.

${ }^{8}$ Non-employer businesses are excluded fromour sample since one of our business performance meas ures is employment growth. Further res earch will examine the likelihood of becoming an employer business across business owner characteris tics during the Great Recession.

${ }_{9}^{9}$ Appendices A-H show weighted results.
} 
because the 2002 SBO provides business owner characteristics as of that year. Some of them, such as owner education, may change over time while others (such as owner race and gender) are less likely to change. To check on this possibility, we isolate the panel of firms in both the 2002 and 2007 SBOs, and compare the owner race and gender data across the years. We find very few cases where these owner characteristics changed over time.

\section{Estimation and Results}

Our two business outcome measures are firm employment growth and survival. Since the LBD provides longitudinal data on SBO firms, we are able to examine business performance differentials across owner characteristic s over time, and in particular, through the Great Recession.

\section{A. Employment Growth}

\section{Methodology}

We test some of the key results in the literature using a series of regression models of the general form:

$$
\begin{aligned}
& Y=\beta_{0}+\beta_{1} \text { Race }+\beta_{2} \text { Sex }+\beta_{3} \text { Age }+\beta_{4} \text { Education }+\beta_{5} \text { Hispanic }+\beta_{6} \text { FirmAge } \\
& +\beta_{7} \text { FirmSize }+\beta_{8} \text { Sector }+\beta_{9} \text { NetJobFlow }+\beta_{10} \text { Year }
\end{aligned}
$$

Where $Y$ is the employment grow th of a given firm $i$ at time $t$ measured as:

$$
Y_{i t}=\frac{x_{i t}-x_{i t-1}}{\left(x_{i t}+x_{i t-1}\right) / 2}
$$

This employment growth rate measure is standard in the labor market flows literature since it offers some important advantages relative to log changes and grow th rates calculated on initial employment. For instance, it accommodates firm exits, ${ }^{10}$ and yields measures that are bounded and symmetric about zero. In addition, it is identical to log changes up to a second-order Taylor Series expansion. See Davis, Haltiwanger and Schuh (1996) for further details.

Race, gender, Age, and Education are firm owner characteristics, FirmAge, FirmSize, and Sector are firm characteristics, NetJobFlow is a county-level measure of net job creation rates computed directly from the LBD, and Year stands for year dummies. Although firm age and size are standard control

\footnotetext{
${ }^{10}$ In fact, it accommodates firm entry and exit as well as surviving firms.
} 
variables in many reduced form models of business performance, they have not been widely applied in the literature in the owner characteristic literature. We are able to include these variables because we link the SBO to the LBD. Prior studies that relied on the SBO alone did not have this information available to them and could not include these controls.

\section{Employment Growth Results}

A pervasive finding in the literature is that firms owned by blacks and women underperform white/male-owned firms and that Asian-owned firms outperform all others. Most studies have concluded that these cross-group differences in firm performance are due to differences in prior work experience, family business backgrounds, and the availability of financial capital (Fairlie and Robb 2007).

With this in mind, our first model regresses employment growth on the owner characteristics and firm-level controls from equation (1). The results are shown in the Table $2 .{ }^{11}$ We find that black-owned businesses have a negative, statistically significant difference in employment grow th compared to whiteowned firms while Asian-owned firms have a positive and significant coefficient. These results are consistent with previous studies examining business performance. Our results also indic ate that womenowned businesses have a lower rate of employment grow th than male (or equally) owned businesses. This is also in-line with previous studies which, as in Coleman and Robb (2012), usually attribute the lower grow th to differences in industry, goals, and access to funding.

By contrast, Hispanic-owned firms have better than average employment growth over the period. Businesses owned by people aged 25 or younger outperform those owned by older people and those owned by people over 55 underperformed those with younger owners. There is also a positive, monotonic relationship between owner education and employment growth. There is a weak but positive correlation between county-level employment grow th and firm-level employment growth. Finally, the firm age and year variables have the expected signs.

The results so far included firm deaths. Next, we rerun the regression focusing on only those firms that survive the entire period. The far columns of Table 2 show the results for the continuing firms. Interestingly, race plays a different role at continuing firms. Black-owned continuing firms outperform white-owned firms and again, Asian-owned firms grow the most. There are no significant differences in employment growth for continuing firms owned by women or equally owned by women and men.

\footnotetext{
${ }^{11}$ These results are froman unweighted sample. As mentioned above, we experimented with using the sample weights from the SBO as well as propensity score weights that accounted for our loss of observations due to failure to link to the LBD. The three sets of results are very similar. Results from the weighted samples are shown in Appendices A-H.
} 
Given that most studies have concluded that differences in firm performance for different races is attributable to access to prior business experience and investment capital, it may be that these effects are most pronounced in the firms' early years. Race and gender effects either reverse themselves or largely disappear for continuing firms. These results are consistent with the idea that established minority and w omen-owned businesses with proven track records have improved access to credit. It may be that race and gender differences have their biggest effects in the firms' early years, particularly impacting the chances of survival.

Next, we look at whether our findings regarding grow th rate differentials across the demographic characteristics of the business owners may have varied during the Great Recession. Tables 3 and 4 show employment growth results for all firms as well as just continuing firms (respectively) by year. They indicate that during the recession and recovery period, Hispanic and Black-owned firms experience lower growth rates compared to non-Hispanic white and Asian-owned businesses. This affect is muted considerably in the case of continuing firms suggesting employment loss due to exit of Black and Hispanic-owned firms was more severe than from exit of white and Asian-owned firms during and after the recession. Future work will examine more closely the role of the housing crisis in this issue.

\section{B. Business Survival}

\section{Methodology}

In order to examine how survival varies across the demographic characteristics of the business owners, we employ survival analysis. ${ }^{12}$ We first estimate the Kaplan-Meier or unconditional survival model for the 2002 SBO firms in our sample. We do so overall, and also by the race, Hispanic origin and gender of the business owner. We then employ the Cox proportional hazard (PH) model (Cox 1972; Cox and Oakes 1984) to estimate the conditional hazard rate of firm $i$ at time $t$. Specifically, we estimate the probability that firm $i$ will fail in the next period conditional on having survived until time $t$, as a function of time-varying as well as time-invariant covariates.

As explained earlier, our data consist of 2002 SBO firms linked to 2002-2011 LBD data. The LBD, thus, allows us to observe year to year whether 2002 SBO firms survive to the next time period (i.e., year). If firm i survives to the next time period t, our failure or closure variable equals 0 , and equals 1 otherwise. Firms that survive up to our last time period (2011) are treated as right-censored observations.

\footnotetext{
${ }^{12}$ Survival analysis is better suited than logistic or OLS to study time to occurrence events. It allows and adjusts for censored data as well as for analyzing time between events rather than predicting occurrence of events.
} 
Formally, the hazard function of firm i can be expressed as a product of two components: :i) a baseline hazard function, $\lambda_{0}(\mathrm{t})=\mathrm{e}^{\alpha(\mathrm{t})}$, representing how the risk of failure changes over time at baseline levels of the covariates, and ii) the risk associated with the covariate values, describing how the hazard varies in response to the explanatory variables: $\exp \left\{\beta_{1} \mathrm{X}_{\mathrm{i} 1}+\beta_{2} \mathrm{X}_{\mathrm{i} 2}+\ldots+\beta_{\mathrm{k}} \mathrm{X}_{\mathrm{ik}}\right\}$. Specifically:

$$
\mathrm{H}_{\mathrm{i}}(\mathrm{t})=\lambda_{0}(\mathrm{t}) \exp \left\{\beta_{1} \mathrm{X}_{\mathrm{i} 1}+\beta_{2} \mathrm{X}_{\mathrm{i} 2}+\ldots+\beta_{\mathrm{k}} \mathrm{X}_{\mathrm{ik}}\right\}
$$

The Cox model emerges from taking the ratio of the hazards, the baseline hazard cancels out and the hazards are proportional at any time. When time-varying covariates are introduced, the hazard function simply becomes:

$\mathrm{H}_{\mathrm{i}}(\mathrm{t})=\lambda_{0}(\mathrm{t}) \exp \left\{\beta_{1} \mathrm{X}_{\mathrm{i} 1}+\beta_{2} \mathrm{X}_{\mathrm{i} 2}+\ldots+\beta_{\mathrm{k}} \mathrm{X}_{\mathrm{ik}}+\beta_{\mathrm{p}} \mathrm{X}_{\mathrm{ip}}(\mathrm{t})\right\}$, where $\mathrm{X}_{\mathrm{ip}}$ is time-varying.

Because some of the covariates are time-varying, the proportionality assumption will not nec essarily hold. We conduct an exploratory analysis to examine hazard proportionality and subsequently estimate an Extended Cox model with time-varying covariates. We address the issue by running a fully interacted model with time to examine differentials in the relative hazard of a given group over time.

\section{Survival Results}

\section{Kaplan-Meier Survival}

We first present Kaplan-Meier (K-M) survival estimates overall and by the race, Hispanic origin and gender of the business owner. The K-M survival function gives the share of businesses that still exist at the end of each time period (years, in our analysis). ${ }^{13}$ As Figure 1 indicates, on average, by the end of our time period (2011), approximately 60 percent of all 2002 SBO-LBD firms in our sample survived the entire study period through 2011.

Figures 2-4 present K-M survival rates across the race, Hispanic origin and gender of the business owners. They show clear differences among the groups. As seen in Figure 2, the probability of survival was the highest for white-owned businesses throughout the entire study period - although the survival probability of Asian-owned businesses was not far behind. In particular, in 2008 at the time of the recession (year 6 in our analysis), approximately 69 percent of businesses owned by whites had survived compared to 59.1 percent for blacks and 65.8 percent for Asians. By the end of our study period

\footnotetext{
${ }^{13}$ The Kaplan-Meier estimation does not account for the left truncation of the lifespans mentioned above, so the estimated survival probabilities are biased. Survival probability estimates are biased upward as short-lived businesses are disproportionately excluded from the sample.
} 
(officially, after the recession), approximately 60 percent of businesses owned by whites had survived compared to 48.7 percent for blacks and 57.2 percent for Asians.

Figure 3 indicates that the survival rate of non-Hispanic businesses is higher than that of Hispanic owners throughout the entire period of analysis. For instance, by the end of 2008, approximately 64.5 percent of Hispanic-owned businesses had survived compared to 69 percent of non-Hispanic businesses. By the end of the period, 60 percent of non-Hispanic businesses had survived relative to 54.6 percent owned by Hispanics.

In Figure 4 we see that the survival probability of male-owned businesses was higher than those owned by females or equally owned by males and females - although the survival probabilities for male and equally-owned businesses were close in magnitude. In 2008, the survival probability for male and equally-owned businesses were 70 and 60 percent respectively while it was 64.5 percent for women. By the end of our study period, survival probabilities were 61, 60 and 55.3 percent for males, equally-owned and female-owned businesses respectively.

These differences in unconditional survival probabilities among groups are confirmed by statistical tests (see Table 5). How ever, these estimates show how survival rates vary across business owners’ demographic characteristics, considering just one characteristic at a time. Other factors such as business size, business sector or owner's age may be correlated with both the demographic characteristics above as well as survival. If they are, our estimates may suffer from omitted variable bias, leading to biased estimates of the relationship between survival and the race, ethnicity and gender of business owners. To control for these variables, we use a Cox PH model and include a number of covariates in our model specification.

\section{Extended Cox Model Results}

Here we examine how survival rates vary across business owners' race, Hispanic origin and gender while also controlling for other factors that may have an effect on business survival. ${ }^{14}$ Specifically, we include the age and education level of the business owner as of 2002 (the SBO survey year), the age of the business as of 2002, the firm size and sector, and the net job flow of the county where the business is located. Note that firm size and sector, and the county-level net job flow are time-varying.

\footnotetext{
${ }^{14}$ We use unweighted data in our analysis since ours is a sub- sample of the entire $2002 \mathrm{SBO}$. As part of our sensitivity analysis, we ran models using weighted data. We find that the weighted and unweighted results are qualitatively the same.
} 
As mentioned earlier, previous studies ${ }^{15}$ have shown that owner characteristics play a role in business survival. Other studies (for instance, Fort et al. 2013, Manjon-Antolin and Arauzo-Carod 2008) have also shown that business age and size are important factors in business survival. Young, less experienced firms tend to have higher failure rates than older ones, and smaller firms are more likely to face more financial constraints such as adequate access to funding, which in turn, may affect access to required technology, skilled labor or good managers. In addition, younger firms tend to be smaller, so this would also help explain the higher failure rates of young small firms. The survival of a business is also tied to sectoral shifts and shocks affecting different industries differently. Finally, county-level net job flow is also included to control for local economic conditions.

Figure 5 shows Cox hazard estimates for the 2002 SBO-LBD firms in our sample. The graph shows an increase in the risk of failure during the Great Recession. During this period, the hazard rate increased by almost 20 percentage points from the initial time period of our analysis.

While all firms experienced higher failure rates during the last recession, one of our goals is to examine whether there exist hazard rate differentials across the race, Hispanic origin and gender of the business owners. To this end, Table 6 shows hazard ratios for all 2002 SBO firms in our sample over the entire 2002-2011 analysis period.

The results indicate that overall (Table 6, column 1), there is a 5 percent higher incidence of business closure for Hispanic business owners compared to non-Hispanic owners even when controlling for potential confounders. We also find evidence that compared to white-owned businesses, black-owned firms fail at a higher rate. In particular, the business failure rate for black-owned businesses is 25 percent higher than that of firms owned by whites. Meanwhile, the failure rate differential between Asian and white-owned businesses is not statistic ally signific ant. Regarding results by gender, we can see that female-owned businesses have an incidence of closure that is 10 percent higher than that of male-owned businesses. Meanwhile, businesses jointly owned by men and w omen are not at a higher risk of failing relative to male-owned firms. These results are consistent with those found in previous studies (Robb \& Fairlie 2006, 2007 and 2008, Coleman \& Robb 2008).

As mentioned earlier, we are interested not only in examining how business survival rates vary across the demographic characteristics of the business owners, but also in how those differences may vary during the Great Recession. ${ }^{16}$ Table 6 presents Cox hazard ratios by time period (Table 6, columns 2 through 9).

\footnotetext{
${ }^{15}$ See, for instance, Fairlie and Robb (2008).

${ }^{16}$ We als o check the proportionality of hazards across our groups of interest, and exploratory analysis revealed that the proportionality assumption did not always hold for the covariates of interest. Our fully-interacted model with time als o addresses this issue.
} 
Our results indicate that while the ranking of failure rates across most demographic characteristics do not qualitatively change over time, their magnitudes do for some groups of interest. Regarding race, we find evidence that the hazard rate of black-owned businesses increases relative to that of whites during the recessionary period, and then reverts back to pre-recession levels - from 22 percent higher in 2007 prior to the recession to 27 and 35 percent higher in 2008 and 2009, and then down to 20 percent in 2010. On the other hand, the hazard rate for Asian businesses becomes statistically undistinguishable from those owned by Whites starting in 2005.

Hispanic-owned businesses experience a widening in the hazard rate differential with respect to nonHispanic businesses during the Great Recession (2008-2009 period). Prior to that, their relative risk had remained fairly stable over time (within 4 percentage points) and at times, not statistically significantly different from non-Hispanic businesses.

Compared to male-owned businesses, the hazard rate of female-owned remains higher, and does not increase a lot during the recession. Meanwhile, the failure rate of equal-owned businesses remains close to or is statistically undistinguishable from that of male-owned businesses.

\section{Conclusions}

Motivated by both the extensive literature documenting the underperformance of minority owned businesses as well as recent papers demonstrating that young and small businesses were disproportionately impacted during the Great Recession, we explored whether or not the Great Recession had differential impacts across owner characteristics. Like much of the literature, our preliminary analysis found that black and w omen-owned businesses underperform white, male-owned businesses in terms of employment growth as well as survival. We also found that Asian-owned businesses either outperform other groups or their business performance is statistically undistinguishable from whiteowned firms. However, when we considered only at continuing firms, black-owned businesses outperform white-owned businesses in terms of employment growth. This finding is consistent with the idea that already successful business owners of all races are less credit constrained than those just starting-out.

In addition, we found that the recession appears to exacerbate the differential in employment grow th and survival probabilities across race and Hispanic origin. These preliminary findings are consistent with the hypothesis that minority-owned businesses may have been hit harder by the recession if both business owners depend on home equity as a means to provide capital for their businesses and foreclosures fell disproportionately on urban minority neighborhoods. Future research will explore this hypothesis more closely by examining minority and women-owned businesses in metropolitan areas that were particularly hard hit by the Great Recession. 
We also plan to examine employer/non-employer transition differentials during the Great Recession, as well as use the 2007 SBO to examine performance differentials across owner characteristics for young firms during the Great Recession.

\section{References:}

Adelino, Manuel, Song Ma and David T. Robinson, (2014), "Firm Age, Investment Opportunities, and Job Creation,” NBER Working Paper 19845.

Coleman, S. and Alicia Robb. 2009. “A Comparison of New Firm Financing by Gender: Evidence from the Kauffman Firm Survey Data”, Small Business Economics,

Steven J. Davis \& John C. Haltiwanger \& Kyle Handley \& Ron S. Jarmin \& Josh Lerner \& Javier Miranda, 2013. "Private Equity, Jobs, and Productivity," NBER Working Papers 19458.

Fairlie, Robert W. 2008. "Estimating the Contribution of Immigrant Business Owners to the U.S. Economy”, Final Report for the U.S. Small Business Administration, Office of Advocacy.

Fairlie, R. and Alicia Robb. 2008. "Gender Differences in Business Performance: Evidence from the Characteristics of Business Owners Survey”, IZA Discussion Paper \# 3718.

Fairlie, R. and Alicia Robb. 2008. "Why Are Black-owned Businesses Less Successful than WhiteOwned Businesses? The Role of Families, Inheritances, and Business Human Capital”, Journal of Labor Economics, 25(2): 289-323.

Fort, Teresa C., John Haltiw anger, Ron S. Jarmin and Javier Miranda, 2013. "How Firms Respond to Business Cycles: The Role of Firm Age and Firm Size,” IMF Economic Review, 95(2), pp. 347-361.

Gerardi, Kristopher S. and Paul S. Willen, (2009), "Subprime Mortgages, Foreclosures, and Urban Neighborhoods.” B.E. Journal in Economic Analysis and Policy, 9(3),

Harhoff, D., Konrad, S. and Michael Woywode 1998."Legal Form, Growth and Exit of West German Firms - Empirical Results for Manufacturing, Construction, Trade, and Service Industries”.Journal of Industrial Economics, 46(4): 453-88.

Headd, Brian. 2003. “Redefining Business Success: Distinguishing Between Closure and Failure”, Small Business Economics, 21(1): 51-61.

Kim, GiSeung. 2007. “The Analysis of Self-Employment Levels Over the Life-Cycle”, Quarterly Review of Economics and Finance, 47(3): 397-410.

Kleiner, Kristoph, (2013), "How Real Estate Drives the Economy: An Investigation of Small Firm Collateral Shock and Employment,” mimeo, Duke University.

Manjon-Antolin, M.C., and J.-M. Arauzo-Carod. 2008. Firm survival: Methods and evidence. Empirica 35(1): 1-24. 
Mian, Atif and Amir Sufi, (2010), "House Prices, Home Equity-Based Borrowing, and the U.S. Household Leverage Crisis,” American Economic Review, 101(6), pp. 2132-56.

Robb, A. and Robert W. Fairlie. 2006. “Access to Financial Capital Among U.S. Businesses: The Case of African-Americ an Firms”, Center for Economic Studies Working Paper \# 06-33

Robb, A. and Robert W. Fairlie. 2007. "Determinants of Business Success: An Examination of AsianOwned Businesses in the United States”, IZA Discussion Paper \# 2566.

Robb, A. and John Wolken. 2002. "Firm, Owner, and Financing Characteristics: Differences Between Female- and Male-owned Small Businesses”, Finance and Economics discussion Series 2002-18, Board of Governors of the Federal Reserve System (U.S.).

Rugh, Jacob S., and Douglas S. Massey, (2010), "Racial Segregation and the Americ an Foreclosure Crisis.” American Sociological Review, 75(5), pp. 629-651.

Van Praag, C. Mirjam. 2003. "Business Survival and Success of Young Small Business Owners”. Small Business Economics. 21: 1-17. 
Table 1. Descriptive Statistics (as of 2002)

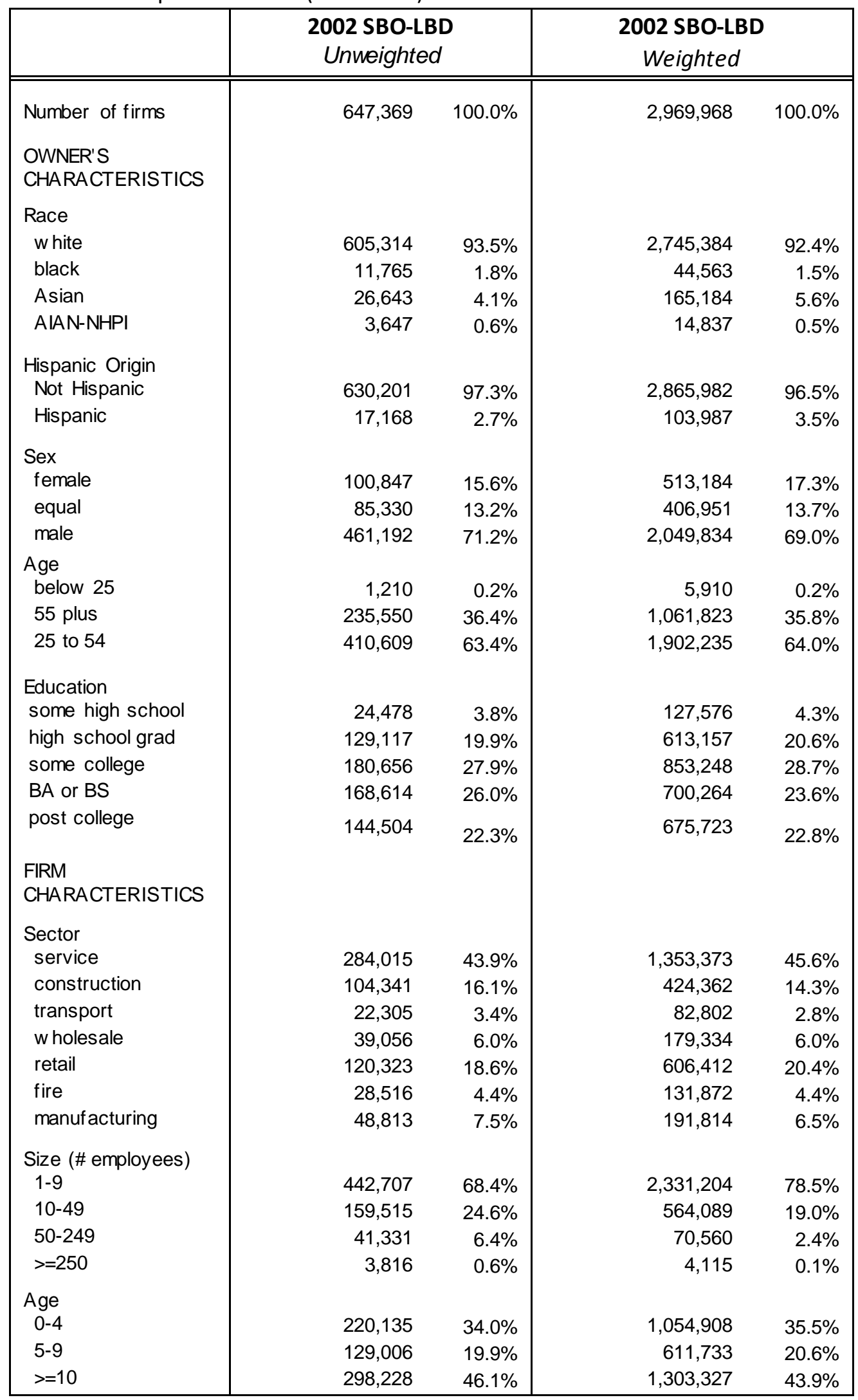




\begin{tabular}{|l|cc|cc|}
\hline \multicolumn{5}{|c|}{ Table 2. Employment Growth Regression - 2002 SBO-LBD } \\
\hline \multicolumn{4}{|c|}{ All Firms } & \multicolumn{2}{c|}{ Continuing Firms Only } \\
Parameter & Coeff & SE & Coeff & SE \\
\hline \hline Intercept & -0.110 & 0.004 & -0.182 & 0.003 \\
\hline Hispanic & 0.016 & 0.001 & 0.01 & 0.001 \\
Non-Hispanic & & & & \\
\hline Black & -0.01 & 0.002 & 0.005 & 0.002 \\
Asian & 0.024 & 0.001 & 0.012 & 0.001 \\
White & & & & \\
\hline Female & -0.008 & 0.001 & -0.001 & 0.001 \\
Equal & 0.012 & 0.001 & 0.000 & 0.001 \\
Male & & & & \\
\hline Age owner below 25 & 0.035 & 0.006 & 0.049 & 0.005 \\
Age owner 55 plus & -0.026 & 0.001 & -0.016 & 0.00 \\
Age owner 25 to 54 & & & & \\
\hline Edu owner hs grad & 0.017 & 0.002 & 0.002 & 0.001 \\
Edu owner some col & 0.022 & 0.001 & 0.004 & 0.001 \\
Edu owner BA or BS & 0.037 & 0.001 & 0.014 & 0.001 \\
Edu owner postcol & 0.052 & 0.002 & 0.018 & 0.001 \\
Edu owner some hs & & & & \\
\hline Firmage 0-4 & 0.242 & 0.001 & 0.299 & 0.001 \\
Firm age 5-9 & -0.025 & 0.001 & 0.005 & 0.001 \\
Firmage 10+ & & & & \\
\hline Firm size 1-9 & -0.097 & 0.003 & -0.02 & 0.003 \\
Firm size 10-49 & -0.033 & 0.003 & -0.026 & 0.003 \\
Firm size 50-250 & -0.015 & 0.003 & -0.016 & 0.003 \\
Firm size 250+ & & & & \\
\hline Sector serv & 0.015 & 0.001 & 0.007 & 0.001 \\
Sector const & -0.015 & 0.001 & -0.016 & 0.001 \\
Sector trans & 0.004 & 0.002 & 0.014 & 0.001 \\
Sector whole & 0.024 & 0.001 & 0.014 & 0.001 \\
Sector retail & 0.000 & 0.001 & 0.006 & 0.001 \\
Sector fire & 0.029 & 0.001 & 0.011 & 0.001 \\
Sector manuf & & & & \\
\hline Net job flow county & 0.003 & 0.000 & 0.002 & 0.000 \\
\hline Year 2002 & 0.302 & 0.001 & 0.282 & 0.001 \\
Year 2003 & 0.11 & 0.001 & 0.244 & 0.001 \\
Year 2004 & 0.099 & 0.001 & 0.212 & 0.001 \\
Year 2005 & 0.094 & 0.001 & 0.204 & 0.001 \\
Year 2006 & 0.12 & 0.001 & 0.225 & 0.001 \\
Year 2007 & 0.15 & 0.001 & 0.228 & 0.001 \\
Year 2008 & -0.051 & 0.001 & 0.137 & 0.001 \\
Year 2009 & -0.067 & 0.001 & 0.12 & 0.001 \\
Year 2010 & 0.001 & 0.172 & 0.001 \\
Year 2011 & & & \\
\hline N & & & & \\
\hline
\end{tabular}




\begin{tabular}{|c|c|c|c|c|c|c|c|c|c|c|}
\hline \multirow{3}{*}{ Year } & \multirow{2}{*}{\multicolumn{2}{|c|}{$\begin{array}{l}\text { Hispanic } \\
\text { Yes }\end{array}$}} & \multicolumn{4}{|c|}{ Owner Race } & \multicolumn{4}{|c|}{ Owner gender } \\
\hline & & & \multicolumn{2}{|l|}{ Black } & \multicolumn{2}{|l|}{ Asian } & \multicolumn{2}{|l|}{ Female } & \multicolumn{2}{|l|}{ Equal } \\
\hline & Coeff. & SE & Coeff. & SE & Coeff. & SE & Coeff. & SE & Coeff. & SE \\
\hline 2003 & 0.042 & 0.005 & -0.032 & 0.006 & 0.044 & 0.004 & -0.009 & 0.002 & 0.023 & 0.002 \\
\hline 2004 & 0.038 & 0.004 & 0.000 & 0.005 & 0.034 & 0.004 & -0.009 & 0.002 & 0.030 & 0.002 \\
\hline 2005 & 0.044 & 0.004 & 0.012 & 0.006 & 0.028 & 0.004 & -0.011 & 0.002 & 0.032 & 0.002 \\
\hline 2006 & 0.037 & 0.004 & 0.005 & 0.006 & 0.022 & 0.004 & -0.008 & 0.002 & 0.019 & 0.002 \\
\hline 2007 & 0.036 & 0.004 & 0.025 & 0.005 & 0.023 & 0.003 & 0.004 & 0.002 & 0.018 & 0.002 \\
\hline 2008 & -0.017 & 0.004 & -0.050 & 0.005 & 0.027 & 0.003 & -0.016 & 0.002 & 0.000 & 0.002 \\
\hline 2009 & -0.006 & 0.004 & -0.022 & 0.006 & 0.045 & 0.004 & -0.012 & 0.002 & 0.002 & 0.002 \\
\hline 2010 & -0.012 & 0.004 & -0.025 & 0.006 & 0.023 & 0.004 & -0.006 & 0.002 & 0.013 & 0.002 \\
\hline 2011 & -0.006 & 0.005 & -0.040 & 0.006 & 0.030 & 0.004 & -0.012 & 0.002 & 0.006 & 0.002 \\
\hline
\end{tabular}

\begin{tabular}{|c|c|c|c|c|c|c|c|c|c|c|}
\hline \multirow[b]{2}{*}{ Year } & \multirow{2}{*}{\multicolumn{2}{|c|}{$\begin{array}{l}\text { Hispanic } \\
\text { Yes }\end{array}$}} & \multicolumn{4}{|c|}{ Owner Race } & \multicolumn{4}{|c|}{ Owner gender } \\
\hline & & & Black & & Asian & & Female & & Equal & \\
\hline & Coeff. & SE & Coeff. & SE & Coeff. & SE & Coeff. & SE & Coeff. & SE \\
\hline 2003 & 0.025 & 0.005 & 0.007 & 0.006 & 0.029 & 0.004 & 0.006 & 0.002 & -0.002 & 0.002 \\
\hline 2004 & 0.029 & 0.004 & 0.024 & 0.006 & 0.016 & 0.003 & 0.000 & 0.002 & 0.009 & 0.002 \\
\hline 2005 & 0.030 & 0.004 & 0.035 & 0.005 & 0.016 & 0.003 & 0.003 & 0.002 & 0.012 & 0.002 \\
\hline 2006 & 0.019 & 0.004 & 0.014 & 0.005 & 0.015 & 0.003 & -0.001 & 0.002 & -0.002 & 0.002 \\
\hline 2007 & 0.023 & 0.004 & 0.017 & 0.005 & 0.017 & 0.003 & 0.006 & 0.002 & 0.000 & 0.002 \\
\hline 2008 & -0.011 & 0.003 & -0.014 & 0.004 & -0.002 & 0.002 & 0.000 & 0.002 & -0.005 & 0.001 \\
\hline 2009 & 0.003 & 0.003 & 0.025 & 0.004 & 0.026 & 0.003 & -0.002 & 0.002 & -0.005 & 0.002 \\
\hline 2010 & 0.006 & 0.003 & 0.008 & 0.004 & 0.000 & 0.002 & 0.002 & 0.001 & 0.005 & 0.001 \\
\hline 2011 & -0.014 & 0.004 & -0.048 & 0.006 & 0.031 & 0.003 & -0.015 & 0.002 & 0.004 & 0.002 \\
\hline
\end{tabular}


Figure 1. Kaplan-Meier Survival Estimates for 2002 SBO Sample

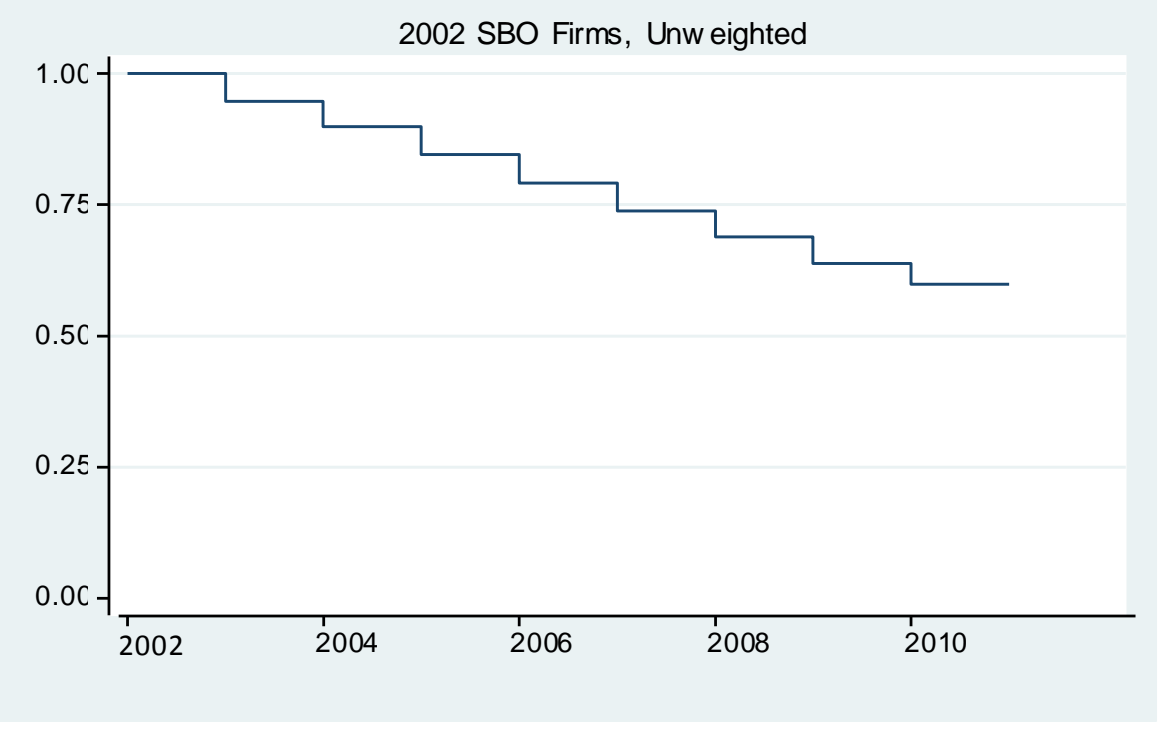

Figure 2. Kaplan-Meier Survival by Owner's Race

K-M Survival by Race 2002 SBO Firms, Unweighted

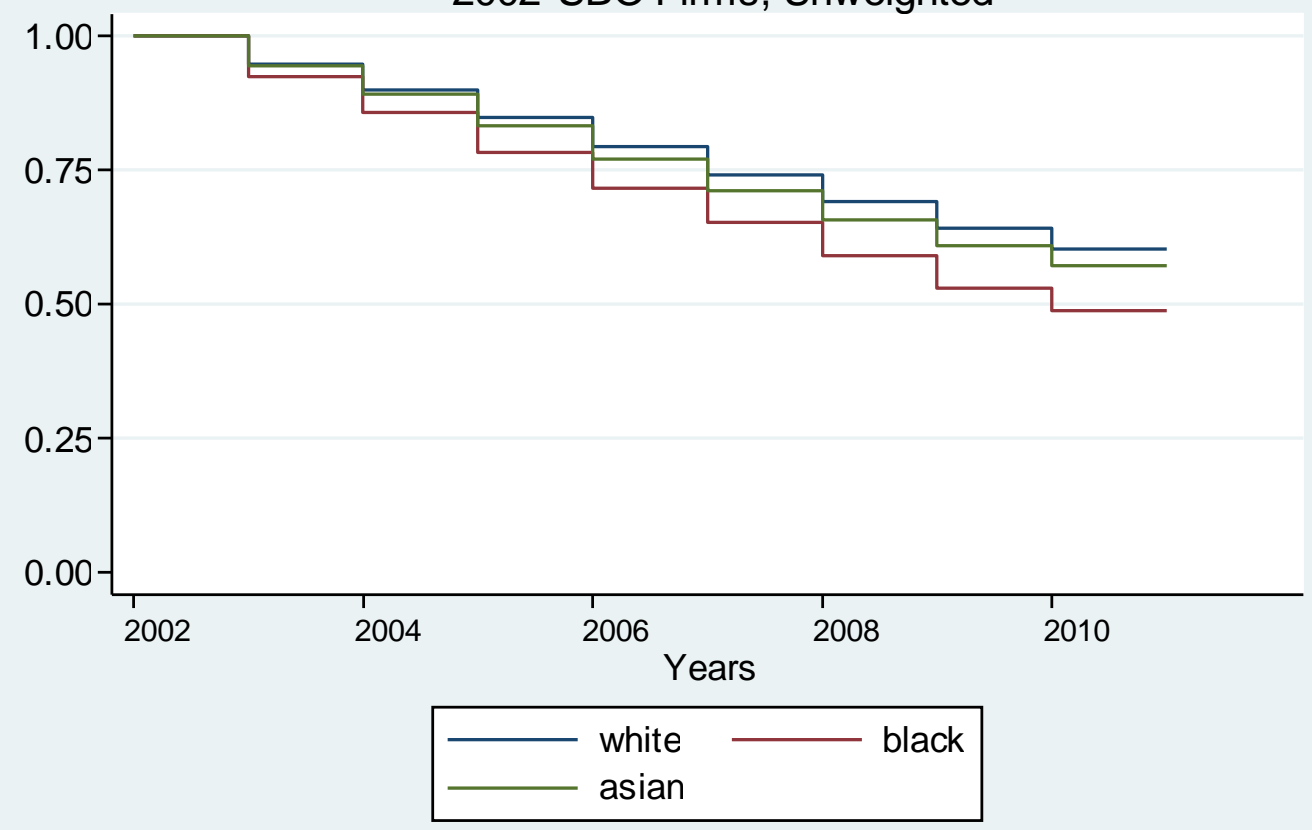


Figure 3. Kaplan-Meier Survival by Owner's Hispanic Origin

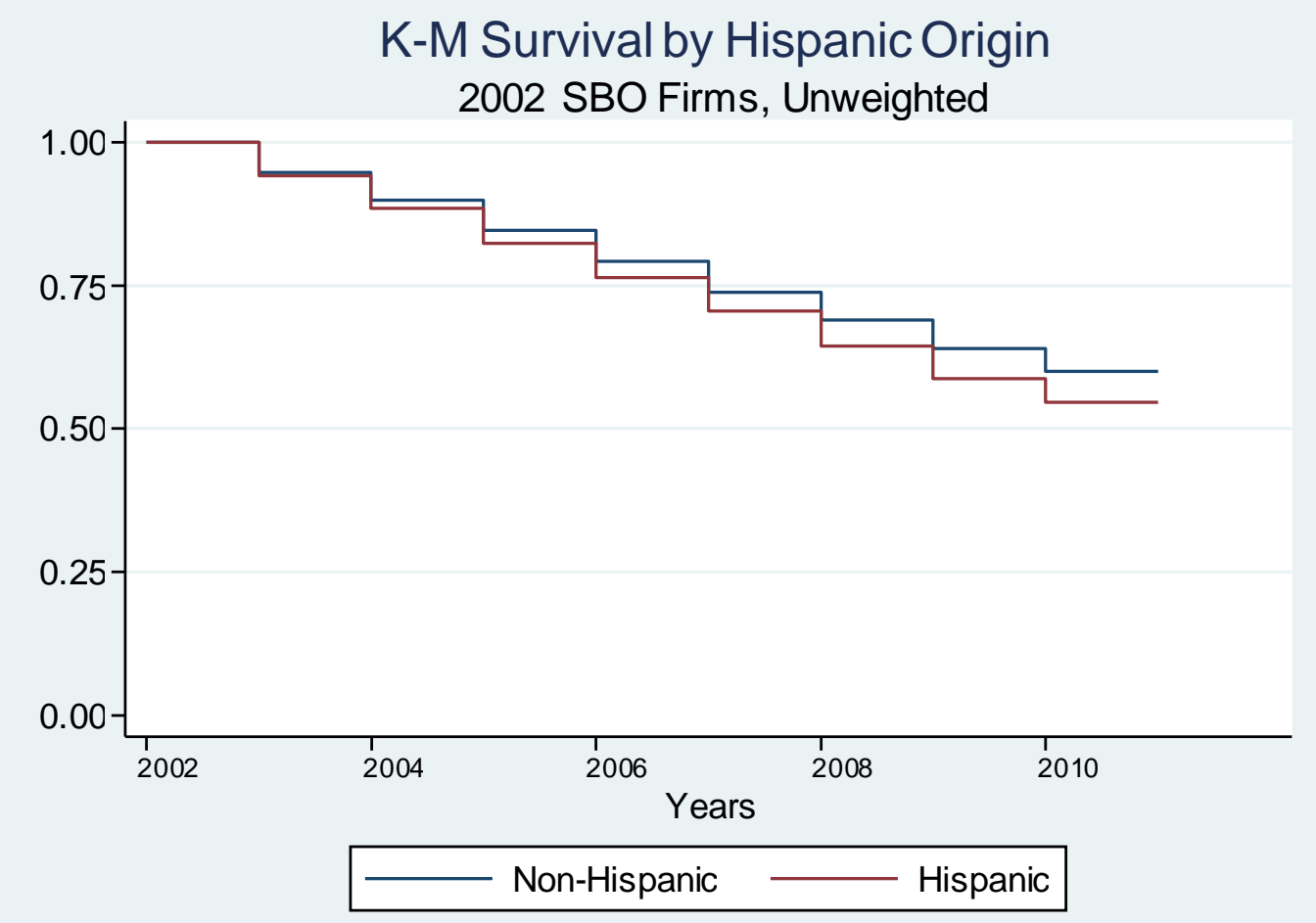

Figure 4. Kaplan-Meier Survival by Owner's gender

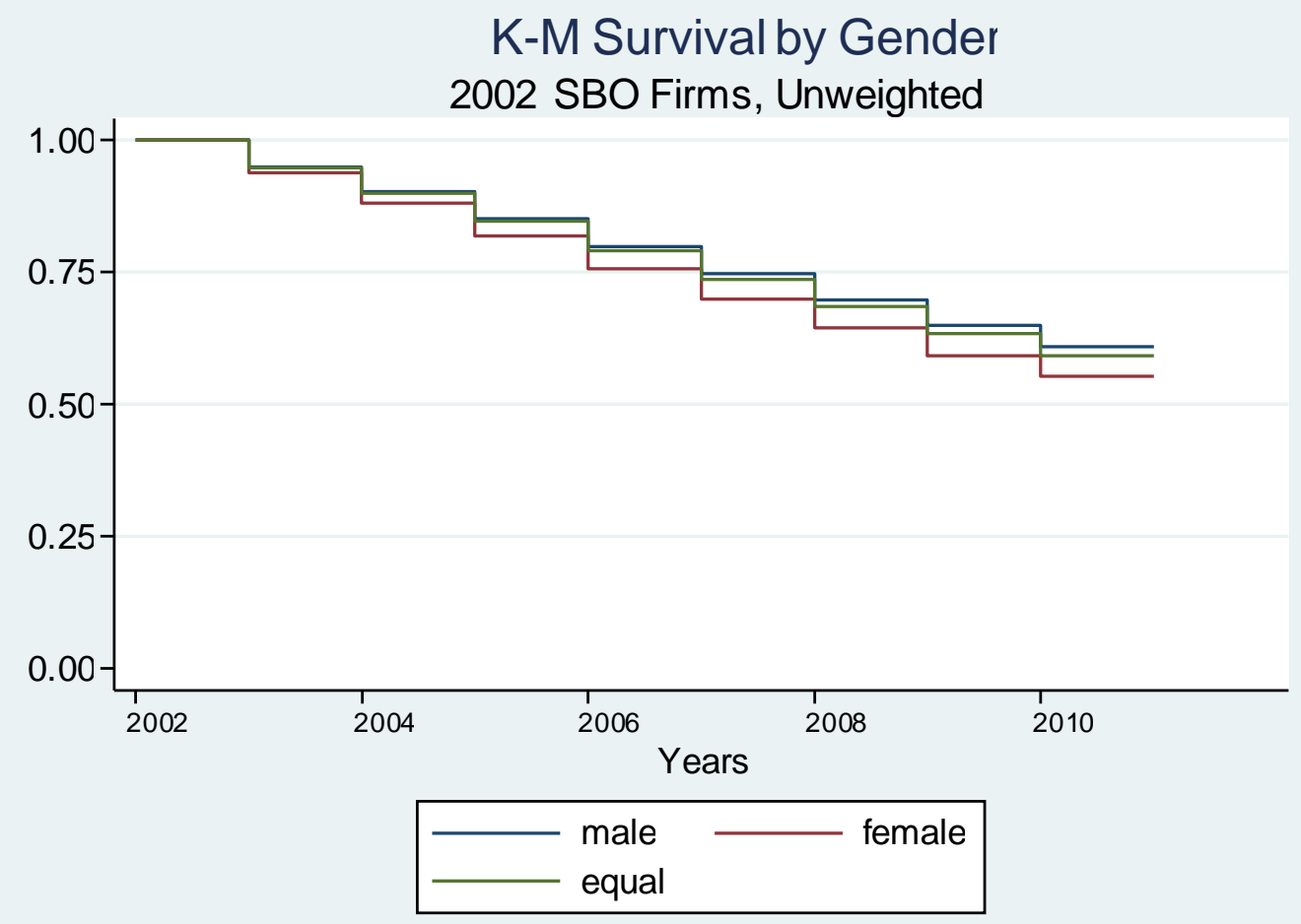


Figure 5. Cox Hazard Function for 2002 SBO-LBD Sample

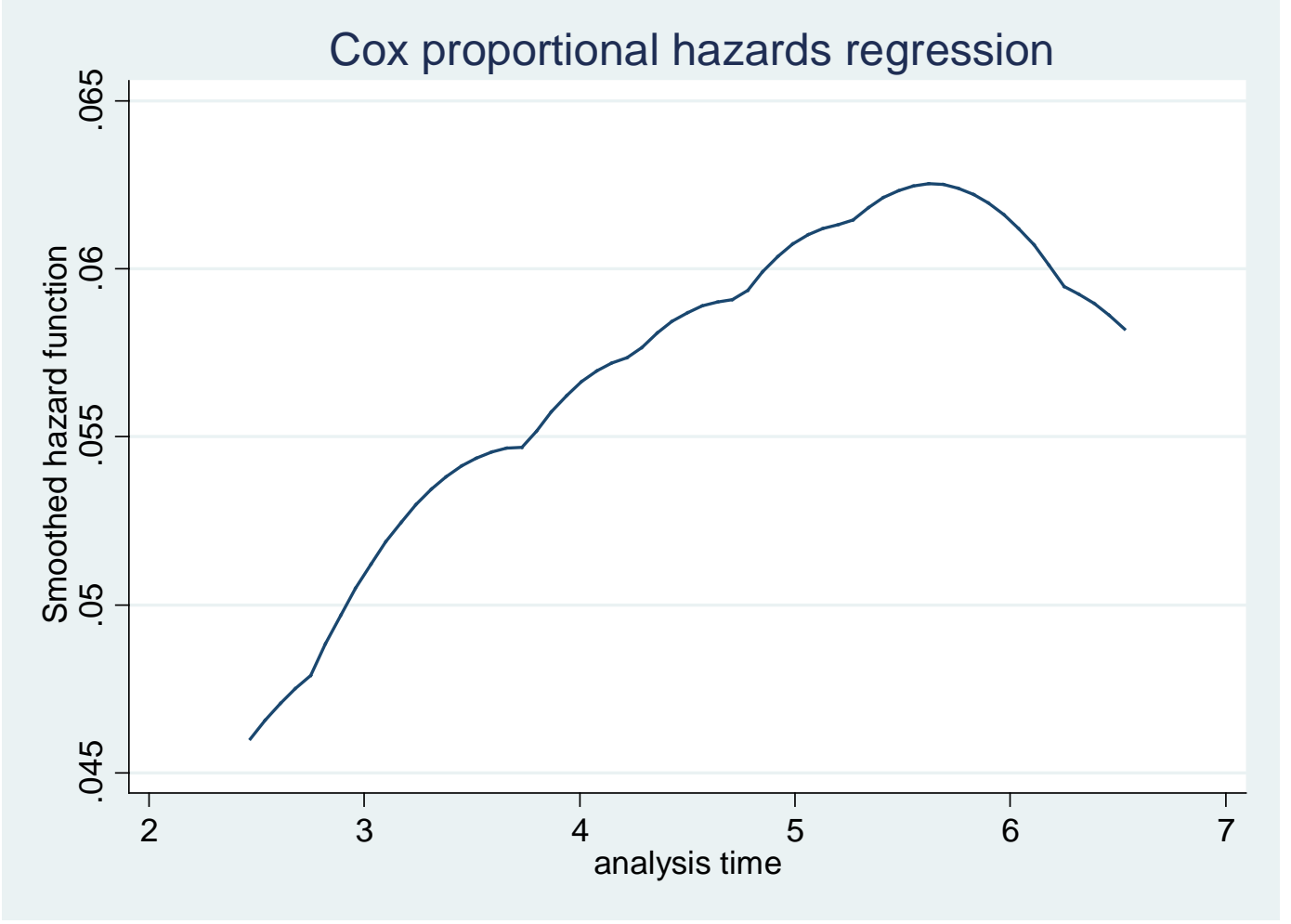

Table 5. Tests for Statistical Differences of K-M Survivals by Group

\begin{tabular}{|l|l|l|l|l|}
\hline & Test & Chi-square & DF & p-value \\
\hline \multirow{3}{*}{ Hispanic origin } & Log-rank & 221.11 & 1 & $<0.000$ \\
& Wilcoxon & 207.67 & 1 & $<0.000$ \\
& Peto-Peto & 206.97 & 1 & $<0.000$ \\
\hline \multirow{3}{*}{ Race } & Log-rank & 968.64 & 3 & $<0.000$ \\
& Wilcoxon & 977.41 & 3 & $<0.000$ \\
& Peto-Peto & 975.95 & 3 & $<0.000$ \\
\hline \multirow{3}{*}{ Gender } & Log-rank & 1341.15 & 2 & $<0.000$ \\
& Wilcoxon & 1375.74 & 2 & $<0.000$ \\
\hline
\end{tabular}


Preliminary and incomplete. Please do not cite or quote without permission

Table 6. Cox Hazard Ratios for 2002 SBO-LBD Sample, Overall \& by Time Period - Unweighted

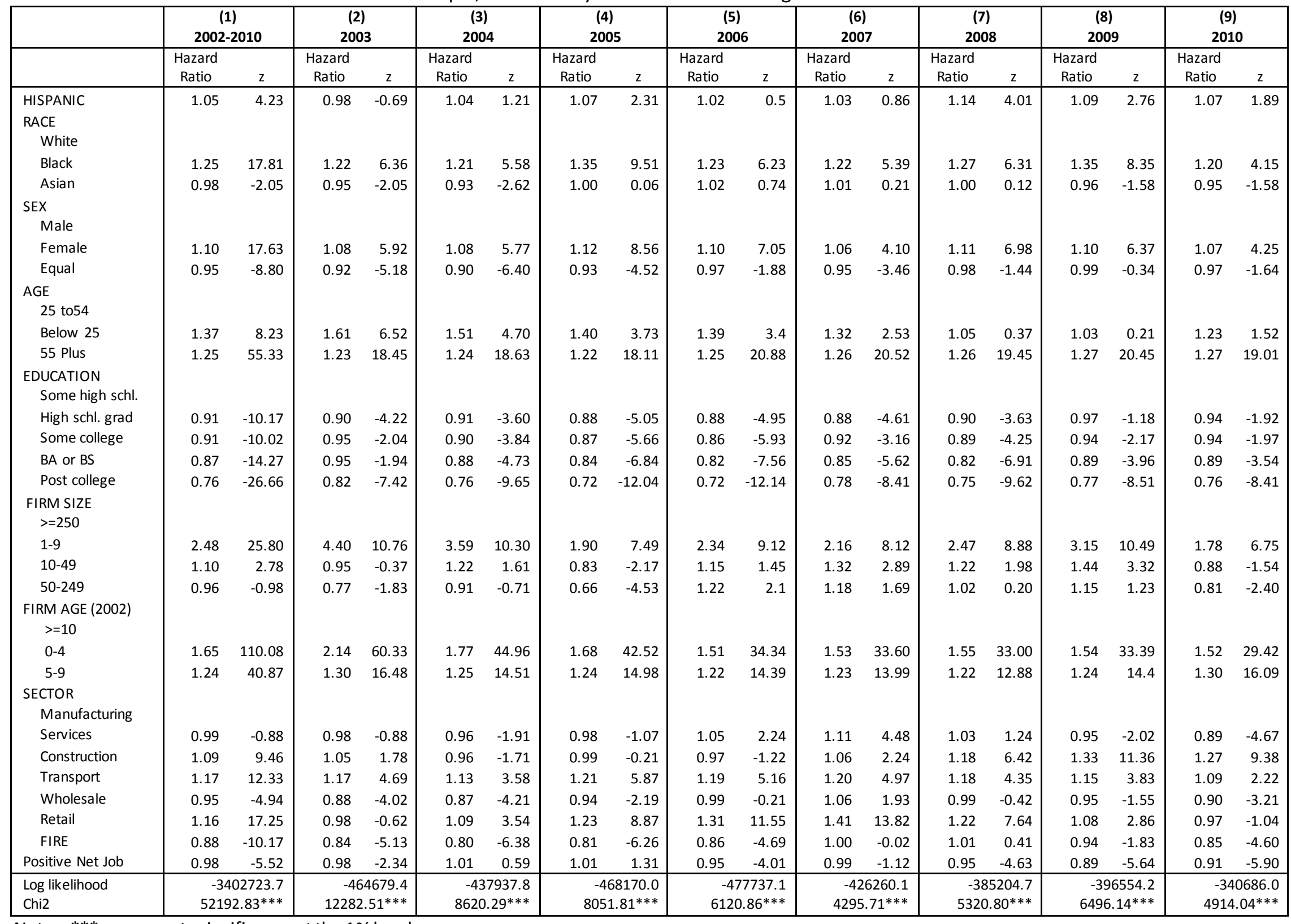

Notes: ${ }^{* * *}$ repres ents significance at the $1 \%$ level. 
Preliminary and incomplete. Please do not cite or quote without permission

\begin{tabular}{|c|c|c|c|c|c|c|}
\hline \multicolumn{7}{|c|}{ Appendix A: Employment Growth Regressions Weighted \& Unweighted: All Firms } \\
\hline \multirow[b]{2}{*}{ Parameter } & \multicolumn{2}{|l|}{ no wgts } & \multicolumn{2}{|l|}{ sbowgt } & \multicolumn{2}{|c|}{ propwgt } \\
\hline & Coeff & SE & Coeff & SE & Coeff & SE \\
\hline Intercept & -0.110 & 0.004 & -0.115 & 0.007 & 0.053 & 0.088 \\
\hline Hispanic & 0.016 & 0.001 & 0.014 & 0.001 & 0.018 & 0.001 \\
\hline \\
\hline Black & -0.010 & 0.002 & -0.010 & 0.002 & -0.008 & 0.002 \\
\hline Asian & 0.024 & 0.001 & 0.024 & 0.001 & 0.028 & 0.001 \\
\hline \multicolumn{7}{|l|}{ White } \\
\hline Female & -0.008 & 0.001 & -0.009 & 0.001 & -0.009 & 0.001 \\
\hline Equal & 0.012 & 0.001 & 0.012 & 0.001 & 0.012 & 0.001 \\
\hline Male & 0.000 & . & 0.000 & . & 0.000 & . \\
\hline \multirow{3}{*}{$\begin{array}{l}\text { Age owner below } 25 \\
\text { Age owner } 55 \text { plus } \\
\text { Age owner } 25 \text { to } 54\end{array}$} & 0.035 & 0.006 & 0.030 & 0.006 & 0.033 & 0.006 \\
\hline & -0.026 & 0.001 & -0.031 & 0.001 & -0.032 & 0.001 \\
\hline & & & & & & \\
\hline Edu owner hs grad & 0.017 & 0.002 & 0.016 & 0.001 & 0.017 & 0.001 \\
\hline Edu owner some col & 0.022 & 0.001 & 0.020 & 0.001 & 0.021 & 0.001 \\
\hline Edu owner BA or BS & 0.037 & 0.001 & 0.036 & 0.001 & 0.035 & 0.001 \\
\hline Edu owner post col & 0.052 & 0.002 & 0.054 & 0.001 & 0.052 & 0.001 \\
\hline \multicolumn{7}{|l|}{ Edu owner some hs } \\
\hline \multirow{3}{*}{$\begin{array}{l}\text { Firm age } 0-4 \\
\text { Firm age } 5-9 \\
\text { Firm age } 10+\end{array}$} & 0.242 & 0.001 & 0.241 & 0.001 & 0.245 & 0.001 \\
\hline & -0.025 & 0.001 & -0.026 & 0.001 & -0.027 & 0.001 \\
\hline & & & & & & \\
\hline Firm size & -0.097 & 0.003 & -0.094 & 0.007 & -0.266 & 0.875 \\
\hline Firm size & -0.033 & 0.003 & -0.033 & 0.007 & -0.209 & 0.570 \\
\hline Firm size $\quad 50-250$ & -0.015 & 0.003 & -0.015 & 0.007 & -0.190 & 0.780 \\
\hline Firm size $\quad 250+$ & & & & & & \\
\hline Sector serv & 0.015 & 0.001 & 0.018 & 0.001 & 0.023 & 0.001 \\
\hline Sector const & -0.015 & 0.001 & -0.010 & 0.001 & -0.011 & 0.001 \\
\hline Sector trans & 0.004 & 0.002 & 0.005 & 0.002 & 0.005 & 0.002 \\
\hline Sector whole & 0.024 & 0.001 & 0.020 & 0.001 & 0.019 & 0.001 \\
\hline Sector retail & 0.000 & 0.001 & 0.003 & 0.001 & 0.004 & 0.001 \\
\hline Sector fire & 0.029 & 0.001 & 0.030 & 0.002 & 0.032 & 0.002 \\
\hline Sector manuf & & & & & & \\
\hline Net job flow county & 0.003 & 0.000 & 0.003 & 0.000 & 0.003 & 0.000 \\
\hline Year 2002 & 0.302 & 0.001 & 0.316 & 0.001 & 0.325 & 0.001 \\
\hline Year 2003 & 0.110 & 0.001 & 0.113 & 0.001 & 0.142 & 0.001 \\
\hline Year 2004 & 0.099 & 0.001 & 0.116 & 0.001 & 0.117 & 0.001 \\
\hline Year 2005 & 0.094 & 0.001 & 0.114 & 0.001 & 0.115 & 0.001 \\
\hline Year 2006 & 0.120 & 0.001 & 0.142 & 0.001 & 0.140 & 0.001 \\
\hline Year 2007 & 0.150 & 0.001 & 0.179 & 0.001 & 0.190 & 0.001 \\
\hline Year 2008 & -0.051 & 0.001 & -0.063 & 0.001 & -0.087 & 0.001 \\
\hline Year $\quad 2009$ & -0.067 & 0.001 & -0.068 & 0.001 & -0.065 & 0.001 \\
\hline Year 2010 & -0.028 & 0.001 & -0.026 & 0.001 & -0.023 & 0.001 \\
\hline Year 2011 & & & & & & \\
\hline
\end{tabular}


Preliminary and incomplete. Please do not cite or quote without permission

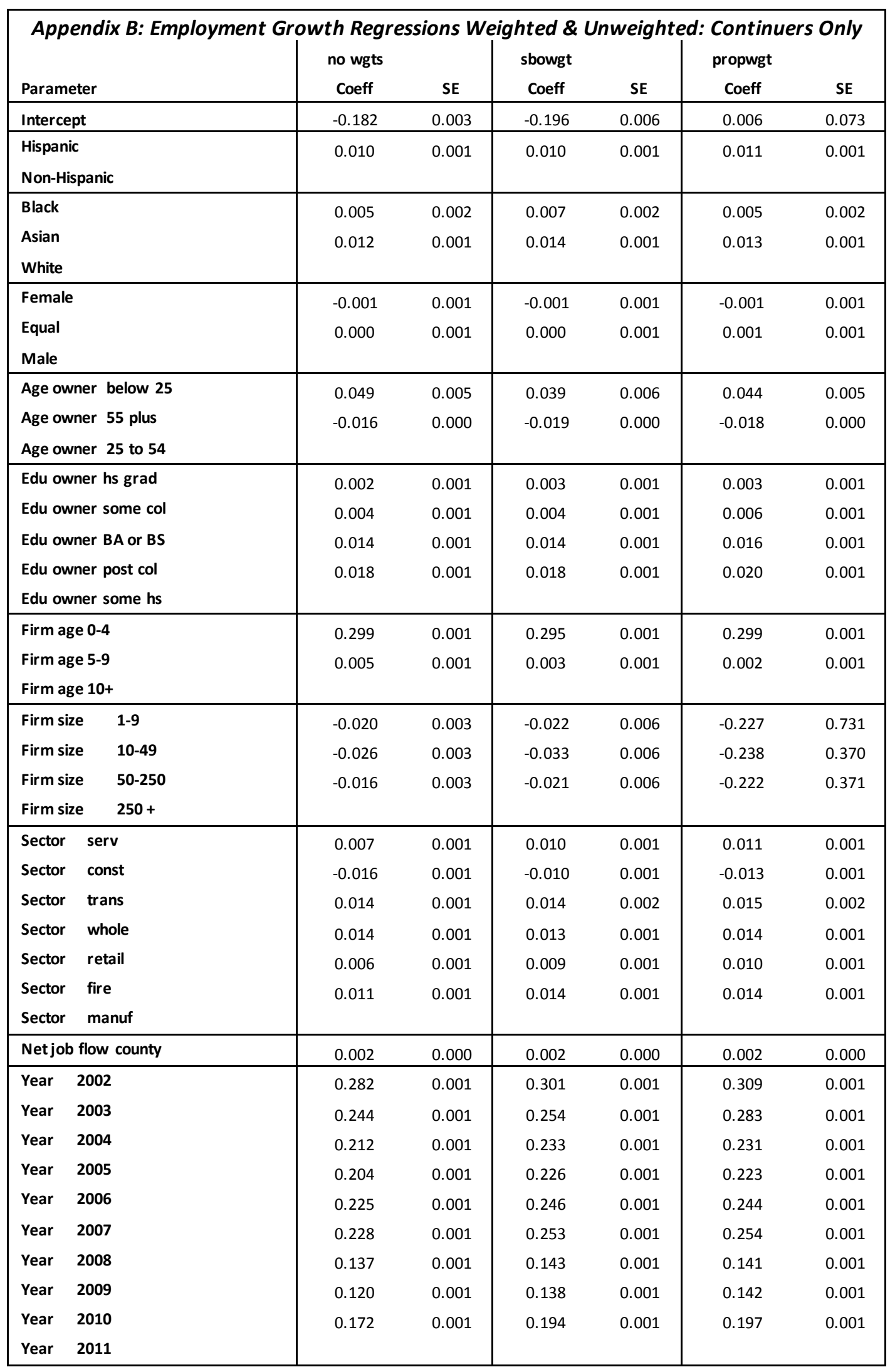


Preliminary and incomplete. Please do not cite or quote without permission

\begin{tabular}{|c|c|c|c|c|c|c|c|c|c|c|}
\hline \multicolumn{11}{|c|}{ Appendix C: Employment Growth Regression by Year - All Firms w/SBOWGT } \\
\hline \multirow{3}{*}{ Year } & \multicolumn{2}{|c|}{ Hispanic } & \multicolumn{4}{|c|}{ Owner Race } & \multicolumn{4}{|c|}{ Owner Gender } \\
\hline & \multicolumn{2}{|l|}{ Yes } & \multicolumn{2}{|l|}{ Black } & \multicolumn{2}{|l|}{ Asian } & \multicolumn{2}{|c|}{ Female } & \multicolumn{2}{|l|}{ Equal } \\
\hline & Coeff. & SE & Coeff. & SE & Coeff. & SE & Coeff. & SE & Coeff. & SE \\
\hline 2003 & 0.031 & 0.004 & -0.019 & 0.006 & 0.052 & 0.003 & -0.008 & 0.002 & 0.023 & 0.002 \\
\hline 2004 & 0.019 & 0.004 & -0.005 & 0.006 & 0.027 & 0.003 & -0.006 & 0.002 & 0.031 & 0.002 \\
\hline 2005 & 0.031 & 0.004 & 0.000 & 0.006 & 0.013 & 0.003 & -0.012 & 0.002 & 0.036 & 0.002 \\
\hline 2006 & 0.031 & 0.004 & -0.006 & 0.006 & 0.014 & 0.003 & -0.011 & 0.002 & 0.023 & 0.002 \\
\hline 2007 & 0.043 & 0.004 & 0.033 & 0.006 & 0.021 & 0.003 & 0.005 & 0.002 & 0.018 & 0.002 \\
\hline 2008 & -0.013 & 0.004 & -0.059 & 0.006 & 0.027 & 0.003 & -0.016 & 0.002 & 0.001 & 0.002 \\
\hline 2009 & -0.002 & 0.004 & -0.016 & 0.006 & 0.049 & 0.003 & -0.013 & 0.002 & 0.002 & 0.002 \\
\hline 2010 & -0.011 & 0.004 & -0.028 & 0.007 & 0.024 & 0.003 & -0.006 & 0.002 & 0.012 & 0.002 \\
\hline 2011 & 0.002 & 0.004 & -0.032 & 0.007 & 0.037 & 0.003 & -0.013 & 0.002 & 0.000 & 0.002 \\
\hline
\end{tabular}

\begin{tabular}{|c|c|c|c|c|c|c|c|c|c|c|}
\hline \multicolumn{11}{|c|}{ Appendix D: Employment Growth Regression by Year - Continuers w/SBOWGT } \\
\hline \multirow{3}{*}{ Year } & \multicolumn{2}{|c|}{ Hispanic } & \multicolumn{4}{|c|}{ Owner Race } & \multicolumn{4}{|c|}{ Owner Gender } \\
\hline & \multicolumn{2}{|l|}{ Yes } & \multicolumn{2}{|l|}{ Black } & \multicolumn{2}{|l|}{ Asian } & \multicolumn{2}{|c|}{ Female } & \multicolumn{2}{|l|}{ Equal } \\
\hline & Coeff. & SE & Coeff. & SE & Coeff. & SE & Coeff. & SE & Coeff. & SE \\
\hline 2003 & 0.017 & 0.004 & 0.028 & 0.007 & 0.045 & 0.003 & 0.007 & 0.002 & -0.003 & 0.002 \\
\hline 2004 & 0.012 & 0.004 & 0.028 & 0.006 & 0.005 & 0.003 & 0.000 & 0.002 & 0.005 & 0.002 \\
\hline 2005 & 0.030 & 0.004 & 0.023 & 0.006 & 0.007 & 0.003 & 0.005 & 0.002 & 0.018 & 0.002 \\
\hline 2006 & 0.015 & 0.004 & 0.011 & 0.006 & 0.004 & 0.003 & -0.006 & 0.002 & -0.004 & 0.002 \\
\hline 2007 & 0.032 & 0.004 & 0.025 & 0.006 & 0.019 & 0.003 & 0.007 & 0.002 & 0.000 & 0.002 \\
\hline 2008 & -0.011 & 0.003 & -0.016 & 0.005 & -0.003 & 0.002 & 0.000 & 0.001 & -0.004 & 0.001 \\
\hline 2009 & 0.004 & 0.003 & 0.025 & 0.005 & 0.029 & 0.002 & -0.001 & 0.002 & -0.003 & 0.002 \\
\hline 2010 & 0.009 & 0.003 & 0.005 & 0.004 & -0.004 & 0.002 & 0.001 & 0.001 & 0.003 & 0.001 \\
\hline 2011 & -0.012 & 0.004 & -0.038 & 0.006 & 0.042 & 0.003 & -0.016 & 0.002 & -0.003 & 0.002 \\
\hline
\end{tabular}


Preliminary and incomplete. Please do not cite or quote without permission

\begin{tabular}{|c|c|c|c|c|c|c|c|c|c|c|}
\hline \multicolumn{11}{|c|}{ Appendix E: Employment Growth Regression by Year - All Firms w/Propensity WGT } \\
\hline \multirow{3}{*}{ Year } & \multicolumn{2}{|c|}{ Hispanic } & \multicolumn{4}{|c|}{ Owner Race } & \multicolumn{4}{|c|}{ Owner Gender } \\
\hline & \multicolumn{2}{|l|}{ Yes } & \multicolumn{2}{|l|}{ Black } & \multicolumn{2}{|l|}{ Asian } & \multicolumn{2}{|c|}{ Female } & \multicolumn{2}{|l|}{ Equal } \\
\hline & Coeff. & SE & Coeff. & SE & Coeff. & SE & Coeff. & SE & Coeff. & SE \\
\hline 2003 & 0.043 & 0.005 & -0.028 & 0.005 & 0.057 & 0.004 & -0.004 & 0.002 & 0.023 & 0.002 \\
\hline 2004 & 0.038 & 0.004 & 0.007 & 0.005 & 0.038 & 0.003 & -0.007 & 0.002 & 0.031 & 0.002 \\
\hline 2005 & 0.044 & 0.004 & 0.015 & 0.005 & 0.029 & 0.003 & -0.008 & 0.002 & 0.029 & 0.002 \\
\hline 2006 & 0.049 & 0.004 & 0.013 & 0.006 & 0.032 & 0.004 & -0.002 & 0.002 & 0.027 & 0.002 \\
\hline 2007 & 0.034 & 0.004 & 0.019 & 0.005 & 0.024 & 0.003 & 0.005 & 0.002 & 0.014 & 0.002 \\
\hline 2008 & 0.002 & 0.004 & -0.036 & 0.005 & 0.048 & 0.003 & 0.001 & 0.002 & 0.017 & 0.002 \\
\hline 2009 & -0.001 & 0.004 & -0.015 & 0.005 & 0.046 & 0.003 & -0.014 & 0.002 & 0.005 & 0.002 \\
\hline 2010 & -0.004 & 0.004 & -0.017 & 0.005 & 0.034 & 0.003 & -0.005 & 0.002 & 0.015 & 0.002 \\
\hline 2011 & -0.006 & 0.004 & -0.028 & 0.006 & 0.039 & 0.003 & -0.009 & 0.002 & 0.005 & 0.002 \\
\hline
\end{tabular}

\begin{tabular}{|c|c|c|c|c|c|c|c|c|c|c|}
\hline \multicolumn{11}{|c|}{ Appendix F: Employment Growth Regression by Year - Continuers w/Propensity WGT } \\
\hline \multirow{3}{*}{ Year } & \multicolumn{2}{|c|}{ Hispanic } & \multicolumn{4}{|c|}{ Owner Race } & \multicolumn{4}{|c|}{ Owner Gender } \\
\hline & \multicolumn{2}{|l|}{ Yes } & \multicolumn{2}{|l|}{ Black } & \multicolumn{2}{|l|}{ Asian } & \multicolumn{2}{|c|}{ Female } & \multicolumn{2}{|l|}{ Equal } \\
\hline & Coeff. & SE & Coeff. & SE & Coeff. & SE & Coeff. & SE & Coeff. & SE \\
\hline 2003 & 0.030 & 0.005 & 0.003 & 0.006 & 0.035 & 0.004 & 0.010 & 0.002 & 0.001 & 0.002 \\
\hline 2004 & 0.028 & 0.004 & 0.030 & 0.005 & 0.017 & 0.003 & 0.002 & 0.002 & 0.013 & 0.002 \\
\hline 2005 & 0.032 & 0.004 & 0.030 & 0.005 & 0.014 & 0.003 & 0.004 & 0.002 & 0.013 & 0.002 \\
\hline 2006 & 0.021 & 0.004 & 0.011 & 0.005 & 0.012 & 0.003 & -0.005 & 0.002 & -0.003 & 0.002 \\
\hline 2007 & 0.014 & 0.004 & 0.000 & 0.005 & 0.018 & 0.003 & 0.003 & 0.002 & -0.001 & 0.002 \\
\hline 2008 & -0.005 & 0.003 & -0.014 & 0.004 & -0.005 & 0.002 & 0.000 & 0.001 & -0.001 & 0.001 \\
\hline 2009 & -0.001 & 0.003 & 0.026 & 0.004 & 0.022 & 0.002 & -0.004 & 0.001 & -0.005 & 0.001 \\
\hline 2010 & 0.014 & 0.003 & 0.009 & 0.004 & 0.001 & 0.002 & 0.003 & 0.001 & 0.004 & 0.001 \\
\hline 2011 & -0.015 & 0.004 & -0.035 & 0.005 & 0.038 & 0.003 & -0.011 & 0.002 & 0.005 & 0.002 \\
\hline
\end{tabular}


Preliminary and incomplete. Please do not cite or quote without permission

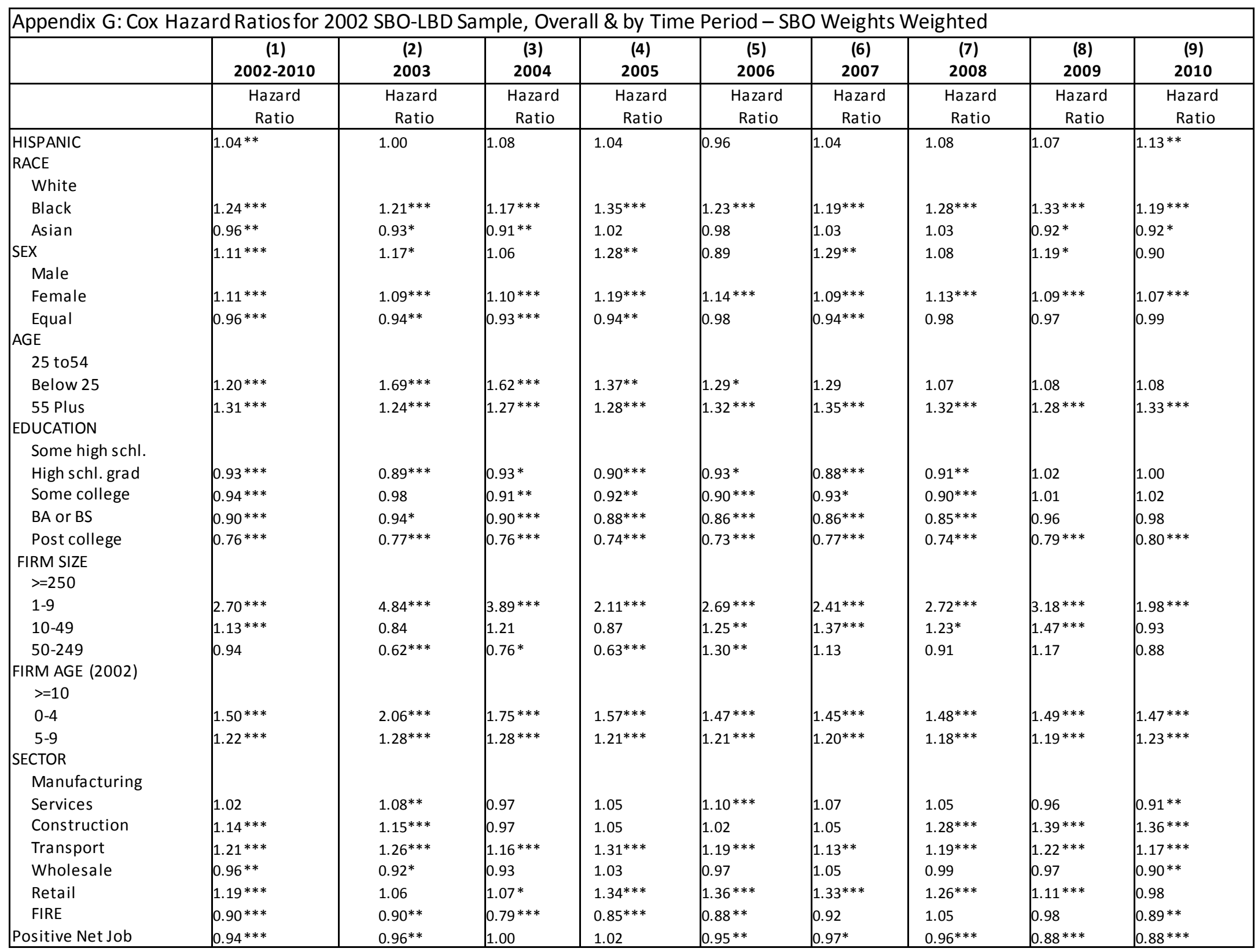

Notes: $* * *, * *, *$ represent statistical significance at the $1 \%, 5 \%$ and $10 \%$ level respectively. 
Preliminary and incomplete. Please do not cite or quote without permission

\begin{tabular}{|c|c|c|c|c|c|c|c|c|c|}
\hline \multicolumn{10}{|c|}{ Appendix H: Cox Hazard Ratios for 2002 SBO-LBD Sample, Overall \& by Time Period - Propensity Weights Weighted } \\
\hline & $\begin{array}{c}1) \\
2002-2010\end{array}$ & $\begin{array}{c}1(2) \\
2003\end{array}$ & $\begin{array}{c}(3) \\
2004\end{array}$ & $\begin{array}{c}14) \\
2005\end{array}$ & $\begin{array}{c}(5) \\
2006\end{array}$ & $\begin{array}{c}(6) \\
2007\end{array}$ & $\begin{array}{c}(7) \\
2008\end{array}$ & $\begin{array}{c}(8) \\
2009\end{array}$ & $\begin{array}{c}(9) \\
2010\end{array}$ \\
\hline & $\begin{array}{c}\text { Hazard } \\
\text { Ratio } \\
\end{array}$ & $\begin{array}{c}\text { Hazard } \\
\text { Ratio }\end{array}$ & $\begin{array}{c}\text { Hazard } \\
\text { Ratio } \\
\end{array}$ & $\begin{array}{r}\text { Hazard } \\
\text { Ratio } \\
\end{array}$ & $\begin{array}{c}\text { Hazard } \\
\text { Ratio }\end{array}$ & $\begin{array}{c}\text { Hazard } \\
\text { Ratio }\end{array}$ & $\begin{array}{c}\text { Hazard } \\
\text { Ratio }\end{array}$ & $\begin{array}{c}\text { Hazard } \\
\text { Ratio }\end{array}$ & $\begin{array}{c}\text { Hazard } \\
\text { Ratio }\end{array}$ \\
\hline $\begin{array}{l}\text { HISPANIC } \\
\text { RACE } \\
\text { White }\end{array}$ & $1.04^{* * *}$ & 1.00 & 1.04 & $1.06^{*}$ & 0.99 & 1.02 & $1.12^{* * *}$ & $1.08 * *$ & $1.09 * *$ \\
\hline Black & $1.23 * * *$ & $1.21^{* * *}$ & $1.19^{* * *}$ & $1.34 * * *$ & $1.21^{* * *}$ & $1.20^{* * *}$ & $1.21 * * *$ & $1.31^{* * *}$ & $1.18^{* * *}$ \\
\hline Asian & $0.96 * * *$ & $0.91^{* * *}$ & $0.89 * * *$ & 1.02 & 0.98 & 0.99 & 1.02 & 0.96 & $0.93 * *$ \\
\hline SEX & $1.15^{* * *}$ & $1.20^{* * *}$ & 1.11 & $1.23^{* * *}$ & 1.11 & $1.25^{* * *}$ & 1.09 & $1.19 * *$ & 0.97 \\
\hline Female & $1.12^{* * *}$ & $1.10^{* * *}$ & $1.11^{* * *}$ & $1.14^{* * *}$ & $1.12^{* * *}$ & $1.08^{* * *}$ & $1.13^{* * *}$ & $1.10^{* * *}$ & $1.11^{* * *}$ \\
\hline $\begin{array}{l}\text { Equal } \\
A G E\end{array}$ & $0.96 * * *$ & $0.94^{* * *}$ & $0.90 * * *$ & $0.94^{* * *}$ & 0.98 & $0.94 * * *$ & 0.99 & 0.99 & 0.97 \\
\hline 25 to 54 & & & & & & & & & \\
\hline Below 25 & $1.38^{* * *}$ & $1.63^{* * *}$ & $1.47^{* * *}$ & $1.43^{* * *}$ & $1.43^{* * *}$ & $1.39 * * *$ & 1.01 & 1.01 & 1.20 \\
\hline 55 Plus & $1.28^{* * *}$ & $1.22^{* * *}$ & $1.25^{* * *}$ & $1.24^{* * *}$ & $1.28^{* * *}$ & $1.31^{* * *}$ & $1.30^{* * *}$ & $1.30^{* * *}$ & $1.32^{* * *}$ \\
\hline $\begin{array}{l}\text { EDUCATION } \\
\text { Some high schl. }\end{array}$ & & & & & & & & & \\
\hline High schl. grad & $0.92 * * *$ & $0.91^{* * *}$ & $0.92^{* * *}$ & $0.88^{* * *}$ & $0.90^{* * *}$ & $0.89 * * *$ & $0.92 * *$ & 0.98 & 0.96 \\
\hline Some college & $0.93 * * *$ & 0.97 & $0.92 * * *$ & $0.88 * * *$ & $0.89 * * *$ & $0.95 *$ & $0.91 * * *$ & 0.96 & 0.95 \\
\hline BA or BS & $0.90 * * *$ & 0.98 & $0.90^{* * *}$ & $0.85^{* * *}$ & $0.85^{* * *}$ & $0.87^{* * *}$ & $0.87^{* * *}$ & $0.93 * *$ & $0.93 *$ \\
\hline Post college & $0.78^{* * *}$ & $0.84^{* * *}$ & $0.77^{* * *}$ & $0.73^{* * *}$ & $0.74^{* * *}$ & $0.79 * * *$ & $0.79 * * *$ & $0.79 * * *$ & $0.78^{* * *}$ \\
\hline $\begin{array}{c}\text { FIRM SIZE } \\
>=250\end{array}$ & & & & & & & & & \\
\hline $1-9$ & $2.90 * * *$ & $5.37^{* * *}$ & $3.27^{* * *}$ & $2.29 * * *$ & $2.42^{* * *}$ & $2.90 * * *$ & $3.20 * * *$ & $3.23^{* * *}$ & $2.41^{* * *}$ \\
\hline $10-49$ & $1.30 * * *$ & 1.05 & 1.00 & 0.93 & $1.33^{*}$ & $1.72^{* * *}$ & $1.81 * * *$ & $1.48 * *$ & 1.18 \\
\hline $50-249$ & $1.13^{* *}$ & 0.82 & 0.75 & $0.72 * *$ & $1.33^{*}$ & $1.60^{* * *}$ & $1.67^{* * *}$ & 1.10 & 1.02 \\
\hline $\begin{array}{l}\text { FIRM AGE (2002) } \\
>=10\end{array}$ & & & & & & & & & \\
\hline $0-4$ & $1.56 * * *$ & $2.08^{* * *}$ & $1.70^{* * *}$ & $1.61^{* * *}$ & $1.32^{* * *}$ & $1.47^{* * *}$ & $1.45^{* * *}$ & $1.52 * * *$ & $1.44^{* * *}$ \\
\hline $5-9$ & $1.19 * * *$ & $1.28^{* * *}$ & $1.21^{* * *}$ & $1.22^{* * *}$ & $1.10^{* * *}$ & $1.20 * * *$ & $1.14 * * *$ & $1.22 * * *$ & $1.24 * * *$ \\
\hline SECTOR & & & & & & & & & \\
\hline Manufacturing & & & & & & & & & \\
\hline Services & $0.98^{* * *}$ & $0.94^{* *}$ & $0.93^{* * *}$ & 0.99 & $1.06 * *$ & $1.07 * *$ & 1.01 & $0.95 * *$ & $0.85^{* * *}$ \\
\hline Construction & $1.10^{* * *}$ & $1.07^{* *}$ & $0.95 *$ & 1.01 & 0.96 & $1.05^{*}$ & $1.20 * * *$ & $1.39 * * *$ & $1.29 * * *$ \\
\hline Transport & $1.15^{* * *}$ & $1.16^{* * *}$ & $1.09 * *$ & $1.19 * * *$ & $1.19 * * *$ & $1.16^{* * *}$ & $1.18^{* * *}$ & $1.15^{* * *}$ & 1.04 \\
\hline Wholesale & $0.96^{* * *}$ & $0.88^{* * *}$ & $0.87^{* * *}$ & 0.97 & $1.07^{*}$ & 1.02 & 1.01 & 0.95 & $0.88^{* * *}$ \\
\hline Retail & $1.17^{* * *}$ & 0.98 & $1.11^{* * *}$ & $1.27^{* * *}$ & $1.35^{* * *}$ & $1.36^{* * *}$ & $1.22 * * *$ & $1.08 * *$ & 0.96 \\
\hline FIRE & $0.86 * * *$ & $0.84^{* * *}$ & $0.80 * * *$ & $0.79 * * *$ & $0.89 * * *$ & $0.92 * *$ & 0.99 & $0.91 * * *$ & $0.80 * * *$ \\
\hline Positive Net Job & $0.98 * * *$ & 0.98 & 1.01 & $1.02 *$ & $0.96 * *$ & 0.99 & $0.96 * * *$ & $0.90 * * *$ & $0.92 * * *$ \\
\hline
\end{tabular}

Notes: $* * *, * *, *$ represent statistical significance at the $1 \%, 5 \%$ and $10 \%$ level respectively. 